\title{
SEWAGE SLUDGE AS NITROGEN AND PHOSPHORUS SOURCE FOR CANE-PLANT AND FIRST RATOON CROPS ${ }^{(1)}$
}

\author{
Ademir Franco ${ }^{(2)}$, Cassio Hamilton Abreu Junior ${ }^{(3)}$, Dilermando Perecin ${ }^{(4)}$, \\ Fernando Carvalho Oliveira ${ }^{(5)}$, Ana Carolina Ribeiro Granja ${ }^{(6)}$ \& Vivian \\ Santoro Braga ${ }^{(2)}$
}

\section{SUMMARY}

The use of sewage sludge in Brazilian agriculture was regulated by the resolution no. 375 Conama, in 2006. However, there is a lack of research to adequate the mineral $\mathrm{N}$ and $\mathrm{P}$ fertilizer doses to be applied in agricultural fields treated with this residue. In a field experiment, the effects of application rates of sewage sludge and mineral $\mathrm{N}$ and $\mathrm{P}$ fertilizers on the productivity and technical characteristics of the cane-plant and first ratoon (residual effect) crops were evaluated. Four doses of sewage sludge $\left(0,3.6,7.2\right.$ and $10.8 \mathrm{t} \mathrm{ha}^{-1}$, dry base), of $\mathrm{N}(0,30,60$ and $\left.90 \mathrm{~kg} \mathrm{ha}^{-1}\right)$ and of $\mathrm{P}_{2} \mathrm{O}_{5}\left(0,60,120\right.$ and $\left.180 \mathrm{~kg} \mathrm{ha}^{-1}\right)$ were combined in a factorial and laid out on randomized block design, a with two replications. To evaluate the residual effect of the sludge, $120 \mathrm{~kg} \mathrm{ha}^{-1} \mathrm{~N}$ and $140 \mathrm{~kg} \mathrm{ha}^{-1}$ of $\mathrm{K}_{2} \mathrm{O}$ were applied in all plots. Sludge application at cane planting, with or without $\mathrm{N}$ and/or $\mathrm{P}$ fertilizer increased the stalk yield from $84 \mathrm{up}$ to $118 \mathrm{t} \mathrm{ha}^{-1}$, with no alteration in the sugarcane quality, compared with the application of NPK fertilizer alone, resulting in a stalk yield of $91 \mathrm{t} \mathrm{ha}^{-1}$. The study of the response surface for stalk yield on lowfertility soil was the basis for a recommendation of mineral $\mathrm{N}$ and $\mathrm{P}$ fertilizer doses for sugarcane implantation as related to sewage sludge application rates. It was also concluded that a sludge application of $10.8 \mathrm{t} \mathrm{ha}^{-1}$, which is the sludge dose established based on the $\mathrm{N}$ criterion according to the resolution Conama $n^{\circ} 375$, could a) reduce the use of mineral $\mathrm{N}$ by $100 \%$ and of $\mathrm{P}_{2} \mathrm{O}_{5}$ by $30 \%$, with increments of $22 \%$ in stalk yield, as a direct effect of sludge application to cane plant crop, and b) increase the stalk yield in the second harvest (first ratoon) by up

\footnotetext{
(1) Parte da Tese do primeiro autor, Programa de Pós-Graduação em Ciência, Centro de Energia Nuclear na Agricultura, Universidade de São Paulo - CENA/USP. Recebido para publicação em abril de 2009 e aprovado em dezembro de 2009.

(2) Doutorando em Ciências, Centro de Energia Nuclear na Agricultura - CENA/USP. Avenida Centenário 303, Caixa Postal 96, CEP 13400-970 Piracicaba (SP). E-mail: ademirfranco@hotmail.com; visbraga@hotmail.com

(3) Professor Doutor, Laboratório de Nutrição Mineral de Plantas, CENA/USP. E-mail: cahabreu@cena.usp.br

(4) Professor Titular, Departamento de Ciências Exatas, Faculdade de Ciências Agrárias e Veterinárias de Jaboticabal, UNESP. Rod. Paulo Donato Castellani s/n, CEP 14884-900 Jaboticabal (SP). E-mail: perecin@fcav.unesp.br

(5) Engenheiro-Agrônomo, Doutor, Biossolo - Agricultura \& Ambiente Ltda. Rua Campos Salles 1818, sala 24. CEP 13416-310 Piracicaba (SP). E-mail: fernando@biossolo.com.br

(6) Mestranda em Ciências, CENA/USP. E-mail: aribeiro@cena.usp.br
} 
to $12 \%$ and sugar yield by up to $11 \%$, by the residual effect of sludge application to sugar cane.

Index terms: technical quality, sugarcane, crop yield, urban wastes, Saccharum spp., response surface.

\title{
RESUMO: LODODE ESGOTO COMO FONTE DE NITROGÊNIO E FÓSFORO NO CULTIVO DE CANA-PLANTA E DA PRIMEIRA CANA-SOCA
}

\begin{abstract}
O uso do lodo de esgoto na agricultura brasileira foi normatizado pela Resolução Conama $n^{\circ} 375$, de 2006. No entanto, faltam pesquisas para adequar as doses complementares de adubos minerais nitrogenado e fosfatado a serem aplicadas em área agrícola tratada com lodo. Avaliaram-se os efeitos de doses de lodo de esgoto e de adubos minerais nitrogenado e fosfatado sobre a produtividade e as características tecnológicas da cana-planta e da primeira soqueira (efeito residual), em campo. Foram aplicadas quatro doses de lodo (0, 3,6, 7,2 e

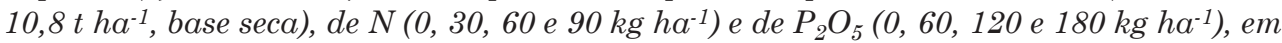
delineamento em blocos casualizados, em esquema fatorial, com duas repetições. Para avaliar o efeito residual do lodo, foram aplicados $120 \mathrm{~kg} \mathrm{ha}^{-1} \mathrm{de} \mathrm{Ne} 140 \mathrm{~kg} \mathrm{ha}^{-1} \mathrm{de} \mathrm{K}_{2} \mathrm{O}$ em todas as plotas. A aplicação de lodo no plantio da cana, combinado ou não com adubo mineral nitrogenado e, ou, fosfatado, aumentou a produtividade de colmos de 84 a $118 \mathrm{th} \mathrm{h}^{-1}$, sem alterar a qualidade tecnológica da cana-de-açúcar, em relação à adubação NPK convencional, que produziu 91 t hat de colmo. O estudo de superfície de resposta para a produtividade de colmo, em solo de baixa fertilidade, permitiu estabelecer sugestão de recomendação de adubo mineral nitrogenado e fosfatado para implantação de canavial, em função da dose de lodo, bem como concluir que a aplicação de 10,8 tha $\mathrm{h}^{-1}$ de lodo, ou seja, da dose estabelecida pelo critério do $N$, conforme Resolução Conama $n^{\circ} 375$, pôde: reduzir o uso de $\mathrm{N}$ mineral em $100 \%$ e o de $\mathrm{P}_{2} \mathrm{O}_{5}$ em $30 \%$, com aumento de produtividade de colmos em $22 \%$, em relação à adubação NPK convencional, como efeito direto do lodo sobre o cultivo da cana-planta; e aumentar a produtividade de colmos da primeira soqueira em até $12 \%$ e a de açúcar em até $11 \%$, como efeito residual do lodo aplicado na cana-planta sobre o cultivo da cana-soca.
\end{abstract}

Termos de indexação: análise tecnológica, cana-de-açúcar, produtividade, resíduos urbanos, Saccharum spp., superfície de resposta.

\section{INTRODUCTION}

As cities increase in size and population density, they generate more waste water, requiring greater sewage treatment capacity to reduce the organic load and pathogenicity of the water returned to rivers and bays. However, the treatment produces a residue with a disposal problem of its own: sewage sludge. A potential solution to this problem is to use sludge as fertilizer, due to the contents of organic matter and plant nutrients, mainly $\mathrm{N}$ and $\mathrm{P}$, the sludge constituents with greatest agricultural value (Corrêa, 2004; Nascimento et al., 2004).

Sewage sludge, adequately conditioned, is already used on sugarcane fields in the state of São Paulo (Brazil's leading cane-growing state), but only on a small scale. The reason is that although this use is one of the most feasible alternatives from a technical and economic standpoint, there are still many doubts among farmers and sewage system managers as to the best fertility management of sludge-treated soil (Abreu Junior et al., 2005, 2008), besides concerns about environmental contamination, e.g., heavy metals, toxic organic compounds and/or pathogens (Bertoncini et al., 2004; Abreu Junior et al., 2005, 2008; Camilotti et al., 2009).

Various studies have reported on sludge application to sugarcane (Oliveira, 2000; Silva et al., 2001; Camilotti et al., 2006; Marques et al., 2007; Tasso Júnior et al., 2007; Chiba et at., 2008, 2009), but most of them focused on doses above those permitted by the technical criteria of Resolution 375 of 2006, issued by the National Environmental Council (CONAMA, 2006), the document that regulates the agricultural use of sewage sludge in Brazil. There are very few studies on the effects of agronomic sludge rates on sugarcane yield. These generally report that sludge application based on the $\mathrm{N}$ criterion, according to CONAMA (2006), is sufficient to supply $100 \%$ of the $\mathrm{N}$ requirement, while other studies have shown that sludge can supply $25 \%$ of the P needed (Franco et al., 2008; Chiba, 2008, 2009). However, these studies on the $\mathrm{N}$ and $\mathrm{P}$ supply capacity of sludge were carried out under different experimental conditions. 
To date there are no reports of factorial experiments to simultaneously evaluate the capacity of sludge to replace mineral $\mathrm{N}$ and $\mathrm{P}$ fertilizers for sugarcane. It is therefore not yet possible to formulate a recommendation for the agronomic use of sewage sludge to fertilize cane fields.

Sugarcane is a semi-perennial crop harvested several times after each planting. New plants grow from the stubble (so-called cane-ratoon) left behind after harvesting the initially planted crop (so-called cane-plant or first regrowth). So, it is agronomically advisable to evaluate the effects of fertilizer accumulation during the entire production phase of each planting, not just for a single harvest. In this sense, Orlando Filho et al. (1999) reported a residual effect of the mineral $\mathrm{N}$ fertilizer applied to cane-plant on ratoon vigor, causing increased yields in subsequent cuttings. Besides, studies on the mineralization of sewage sludge demonstrate that approximately $30 \%$ of organic $\mathrm{N}$ is mineralized in the first year of cultivation (Boeira et al., 2002) and $10 \%$ in the second year (Cogger et al., 2004), calling for an evaluation of the residual sludge effect to formulate recommendations for supplementary mineral fertilization of cane fields. However, there are very few studies in Brazil analyzing the effects of continued sludge application on sugarcane (Oliveira, 2000; Có Junior et al., 2008; Franco et al., 2008), and none of these evaluated the residual effect of sludge applied to cane-plant on the second harvest (first ratoon).

Therefore, the purpose of this experiment was to evaluate the effects of sewage sludge rates and mineral $\mathrm{N}$ and $\mathrm{P}$ sources on the yield and technical characteristics of sugarcane and the residual effect on the first ratoon crop, by means of response surface modeling, to enable a recommendation for mineral fertilization of sugarcane treated with sewage sludge.

\section{MATERIAL AND METHODS}

The experiment was set up in a commercial cane field in the municipality of Capivari, São Paulo, Brazil. This area was chosen because it is included in a project of sludge use on sugarcane, although the field studied had not been treated with sewage sludge until then.

The local climate is moist tropical (Cwa on the Köppen scale), with relatively dry winters and hot and humid summers. Annual rainfall was 1,565 and $1,615 \mathrm{~mm}$, respectively, in the periods from September 2005 to September 2006 (first growth) and from September 2006 to October 2007 (second growth, from ratoons), according to records of the company Usina Cosan S/A.

The soil, classified as dystrophic Yellow Argisol (Argissolo Amarelo distrófico) (Embrapa, 1999)/Typic Hapludult (United States, 1999), was sampled before setting up the experiment for fertility analysis and characterizing potentially toxic elements (Table 1), according to the Resolution 375 (CONAMA, 2006). The concentrations of the potentially toxic elements were below the safety limits (CETESB, 2005), enabling sludge applications in this area.

The sludge was obtained from the Jundiaí Waste Treatment Station, operated under concession by the Companhia Saneamento de Jundiaí, in the municipality of Jundiaí, state of São Paulo. The sludge was generated in a biological system of complete mixture in aerated ponds, followed by sedimentation ponds. The biological sludge was stabilized in the sedimentation ponds for about 12 months, resulting in an organic matter content (dry solids) of $<70 \%$. The sludge was then further treated with polymers, centrifuged and air-dried for 120 days, with periodic mechanical turnover of the piles, to significantly reduce the presence of pathogenic agents and to obtain

Table 1. Chemical characterization of the soil in the experimental area in July/2005

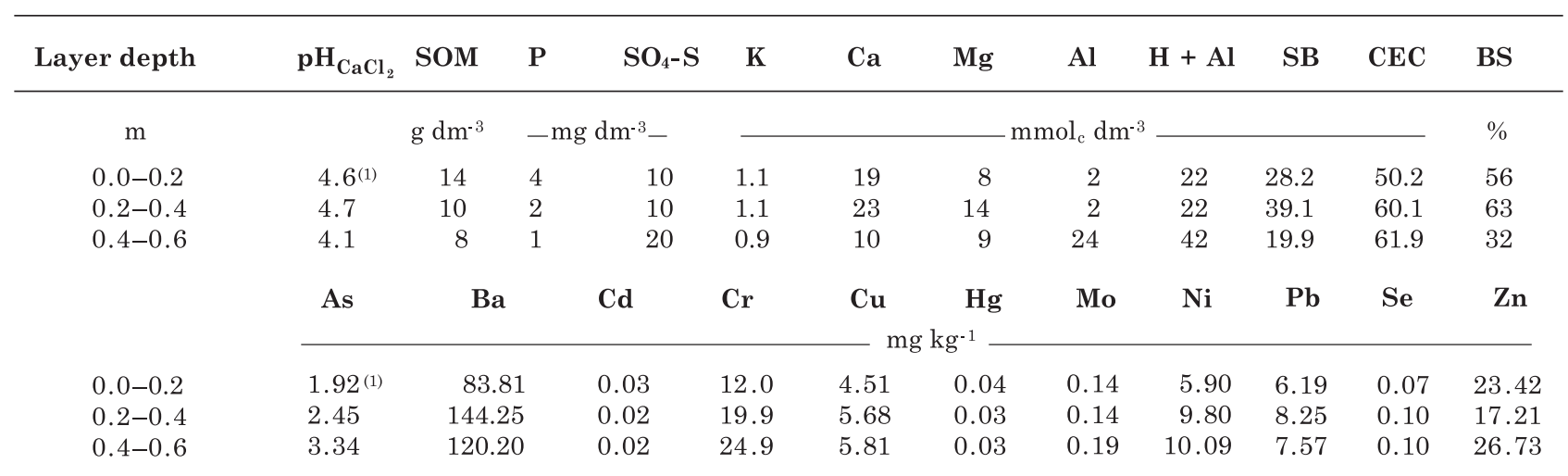

${ }^{(1)}$ Results of the analysis of soil fertility (Raij et al., 2001) and potentially toxic elements obtained by inductively coupled plasma mass spectrometry (ICP-MS), in an extract obtained by microwave-assisted acid digestion, by method 3051A according to manual SW-846 (USEPA, 2006), both analyses as indicated by Conama Resolution 375 (CONAMA, 2006) for agricultural use of sewage sludge. 
a material with up to $25 \%$ solids. The sewage sludge, conforming with the recommendation of Resolution 375 (CONAMA, 2006), had a moisture content of $78 \%$ $(\mathrm{m} / \mathrm{m})$ and $\mathrm{pH}$, measured in water, of 5.8. The total concentrations (dry base) of organic C, total $\mathrm{N}$, ammoniacal $\mathrm{N}$, nitrate/nitrite $\mathrm{N}, \mathrm{P}, \mathrm{K}, \mathrm{Ca}, \mathrm{Mg}, \mathrm{S}$, and $\mathrm{Na}$ were, respectively, 322, 29.7, 2.2, 0.02, 10.49, $2.75,19.03,2.75,17.14$, and $2.06 \mathrm{~g} \mathrm{~kg}^{-1}$, and the respective concentrations of $\mathrm{As}, \mathrm{Ba}, \mathrm{Cd}, \mathrm{Cu}, \mathrm{Cr}, \mathrm{Hg}$, $\mathrm{Mo}, \mathrm{Ni}, \mathrm{Pb}$, Se, and $\mathrm{Zn}$ were 4.22, 600, 13.95, 304, 278, 1.05, 9.75, 65.6, 202, 1.84, and 1,869 $\mathrm{mg} \mathrm{kg}^{-1}$. The sludge concentrations of potentially toxic elements were below the limits established in Resolution 375 (CONAMA, 2006), indicating suitability for agricultural use.

The sugarcane cultivar used was RB 85-5536, which is a medium/late cycle variety, very responsive to the application of mineral fertilizers, with high stalk and sugar yields when grown under favorable conditions for its development (Maule et al., 2001).

Prior to the experiment, in August 2005, dolomitic lime (total relative neutralizing power $=62 \%$ ) was applied at rate of $500 \mathrm{~kg} \mathrm{ha}^{-1}$ in the entire area, to raise base saturation (BS) to $60 \%$ (Spironello et al., 1996). The experimental plots consisted of seven 12 $\mathrm{m}$-long rows of sugarcane, spaced $1.40 \mathrm{~m}$ apart. The evaluated area consisted of the three central rows, disregarding $2.0 \mathrm{~m}$ at either end of each row.

The sewage sludge was applied before planting in September 2005 in the furrows, at doses of $0,3.6,7.2$, and $10.8 \mathrm{t} \mathrm{ha}^{-1}$, equivalent to $0,33,66$, and $100 \%$ of the recommended $\mathrm{N}$ supply, according to Resolution 375 (CONAMA, 2006). Nitrogen, in the form of urea, was applied at doses of $0,30,60$, and $90 \mathrm{~kg} \mathrm{ha}^{-1} \mathrm{~N}$, equivalent to $0,33,66$, and $100 \%$ of the recommendation for the experimental area (Spironello et al., 1996), in proportions of $1 / 3$ applied at planting and 2/3 applied later as side dressing. Phosphorous, in the form of triple superphosphate, was applied in single doses, at planting only, of $0,45,90$, and $180 \mathrm{~kg} \mathrm{ha}-1 \mathrm{P}_{2} \mathrm{O}_{5}$, equivalent to $0,33,66$, and $100 \%$ of the recommended supply. Since sewage sludge is poor in potassium (around $1 \mathrm{~g} \mathrm{~kg}^{-1}$ ), this nutrient had to be supplied with $160 \mathrm{~kg} \mathrm{ha}^{-1} \mathrm{~K}_{2} \mathrm{O}$ at planting, in the form of potassium chloride, on all plots.

To evaluate the residual effect of the sludge applied to cane-plant on the first ratoon growth (after the first harvest), in October 2006, conventional mineral NK fertilizers were applied at rates of $120 \mathrm{~kg} \mathrm{ha}^{-1} \mathrm{~N}$, in the form of urea, and $140 \mathrm{~kg} \mathrm{ha}^{-1} \mathrm{~K}_{2} \mathrm{O}$, in the form of potassium chloride, and incorporated into the soil of the entire experimental area.

The cane stalks were harvested after burning off the dead leaves and leaf sheaths, in September 2006 for cane-plant and in October 2007 for cane-ratoon. The stalk yield, in tonnes (metric tons) per hectare, was evaluated in the field using a scale suspended from a winch. The technical variables of the cane were assessed by total soluble solids (Brix), juice sucrose (Pol), fibers, reducing sugars, Pol in cane, purity, total reducing sugars and total recoverable sugar (TRS), according to the method described by Prado \& Pancelli (2006).

To permit an analysis of the effect of the rates of sludge, $\mathrm{N}$ and $\mathrm{P}$ on the dependent variables by the response surface method, the experiment was arranged in a randomized block design, in a $4 \times 4 \times 4$ factorial scheme, with confounded degrees of freedom for triple interaction, with two replications distributed in eight blocks (16 treatments per block), for a total of 128 field plots. The results were submitted to variance analysis by single and multiple regression, along with response surface modeling, resulting in an equation of the following type: $\mathrm{Y}=\mathrm{a}+\mathrm{bS}+\mathrm{cN}+\mathrm{dP}+\mathrm{eSN}+$ $\mathrm{fSP}+\mathrm{gPN}+\mathrm{hS}^{2}+\mathrm{iN}^{2}+\mathrm{jP}^{2}$, where $\mathrm{S}$ is the sludge dose $\left(\mathrm{t} \mathrm{ha}^{-1}\right), \mathrm{N}$ is the $\mathrm{N}$ dose $\left(\mathrm{kg} \mathrm{ha}^{-1}\right)$ and $\mathrm{P}$ is $\mathrm{P}_{2} \mathrm{O}_{5}$ dose $\left(\mathrm{kg} \mathrm{ha}^{-1}\right)$. Herein after, unless specified otherwise, the sludge rates in $\mathrm{t} \mathrm{ha}^{-1}$ refer to the application of dry material.

\section{RESULTS AND DISCUSSION}

The average cane-plant stalk yield per hectare (tonnes of cane per hectare- $\mathrm{TCH}$ ), as a function of the sludge rates, $\mathrm{N}$ and $\mathrm{P}$, varied from 55 to $118 \mathrm{t} \mathrm{ha}^{-1}$ (Figure 1). The productivity of the treatment with NPK mineral fertilizer was $91 \mathrm{t} \mathrm{ha}^{-1}$. In another study, cultivar RB 85-5536, grown for 12 months on a psammitic dystrophic Red-Yellow Latosol (Typic Hapludox), treated with conventional mineral fertilization, produced an average of $98 \mathrm{t} \mathrm{ha}^{-1}$ of stalk (Gomes, 2003). A higher yield was reported by Maule et al. (2001) who obtained $154 \mathrm{t} \mathrm{ha}^{-1}$, cultivating the same variety for 18 months in Red-Yellow Argisol (Hapludult). This is to be expected, because cane grown for 12 months is less productive than when grown for 18 months (Silva et al., 2008). Therefore, the yields of cane-plant grown for 12 months in this study can be considered excellent, particularly in the treatments with 7.2 and $10.8 \mathrm{t} \mathrm{ha}^{-1}$ sludge.

The response surface modeling study revealed the effects of the treatments on the stalk yield of the caneplant. Greatest increases were obtained with the sludge rates, followed by $\mathrm{P}$ doses, and lastly by $\mathrm{N}$ applications. Linear and quadratic effects were observed, according to the equation: $\mathrm{TCH}\left(\mathrm{t} \mathrm{ha}^{-1}\right)=$ $58.80+5.2 \mathrm{~S}+0.17 \mathrm{~N}+0.18 \mathrm{P}-0.15 \mathrm{~S}^{2}-0.0007 \mathrm{~N}^{2}$ $-0.0006 \mathrm{P}^{2}\left(\mathrm{R}^{2}=0.82 ; \mathrm{p}<0.05\right)$.

The highest stalk yields (96 to $118 \mathrm{t} \mathrm{ha}^{-1}$ ) were obtained in the treatments with application of $10.8 \mathrm{t} \mathrm{ha}^{-1}$ sludge, when compared with application with the NPK fertilizer treatment $\left(91 \mathrm{t} \mathrm{ha}^{-1}\right)$ (Figure 1). Marques et al. (2007) evaluated doses of 10, 20 and $40 \mathrm{t} \mathrm{ha}^{-1}$ sludge from the Waste Treatment Station of Suzano (estate of São Paulo), applied to cane grown on a Dark Red Latosol (Oxisol). In another 

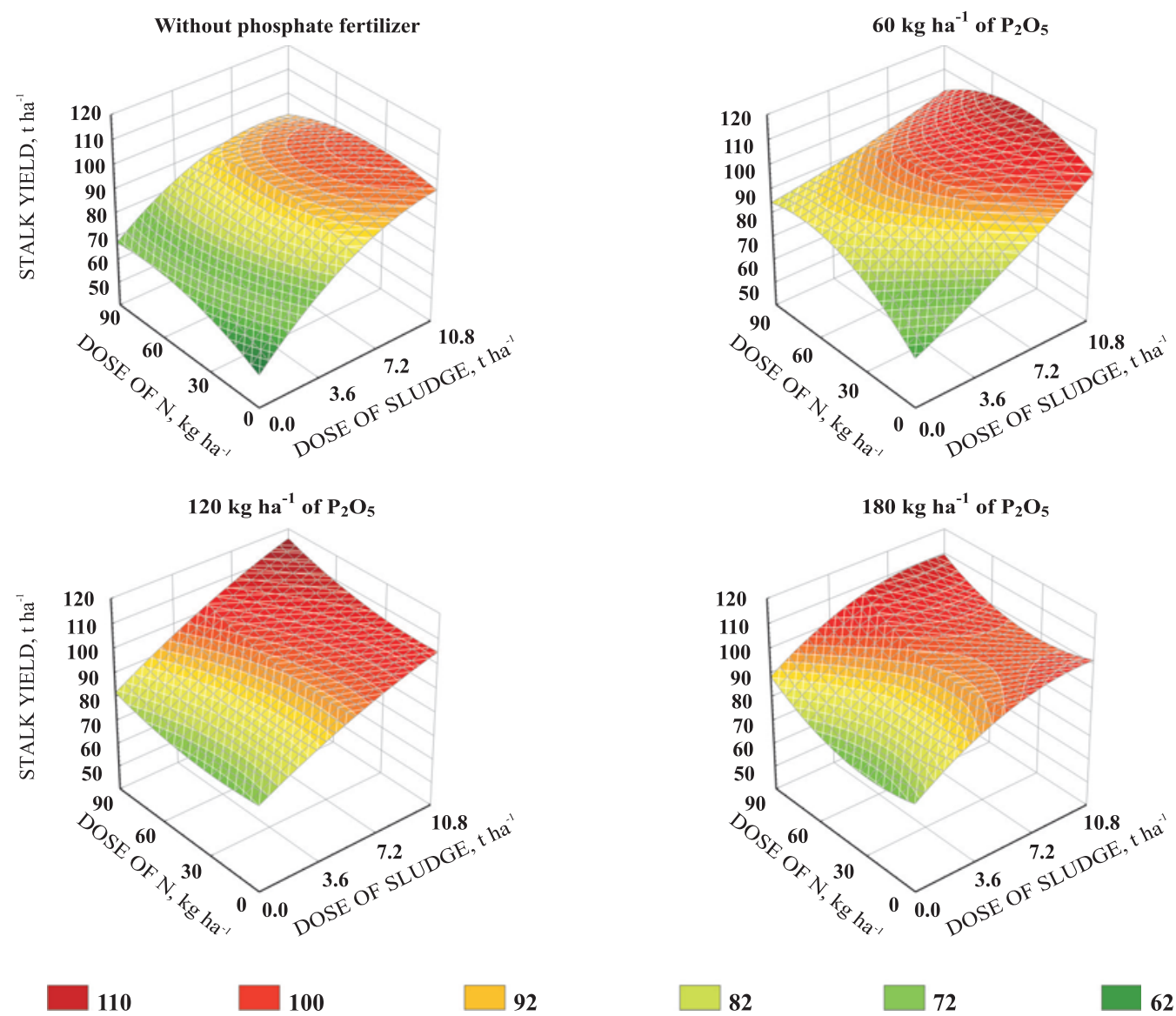

Figure 1. Average cane stalk yield (tonnes of cane per hectare-TCH) of cane-plant in function of the sludge, nitrogen and phosphorous rates.

study, Oliveira (2000) tested doses of 33, 66 and $99 \mathrm{t} \mathrm{ha}^{-1}$ sludge from the Waste Treatment Station of Barueri (metropolitan area of São Paulo, capital district) on cane grown on Red-Yellow Latosol (Typic Hapludox). These authors, differently from ours results, found that the productivity of cane-plant was not changed by sludge rates and that there was no difference between the treatments with sludge and mineral fertilizer. The absence of an effect of sludge was attributed to the high fertility of the soil studied in the first and to lack of rainfall (Indian summer) and/or the short growing period (316 days, about 11 months) in the second study.

In this study, the maximum stalk productivity estimated by the statistical model was $120 \mathrm{t} \mathrm{ha}^{-1}$, with application of $10.8 \mathrm{t} \mathrm{ha}^{-1}$ sludge and complementation via mineral fertilizer of $53 \mathrm{~kg} \mathrm{ha}^{-1} \mathrm{~N}$ and $125 \mathrm{~kg} \mathrm{ha}^{-1}$ $\mathrm{P}_{2} \mathrm{O}_{5}$. Nevertheless, the sludge dose of $10.8 \mathrm{t} \mathrm{ha}^{-1}$ with application of $125 \mathrm{~kg} \mathrm{ha}^{-1} \mathrm{P}_{2} \mathrm{O}_{5}$ would yield $112 \mathrm{t} \mathrm{ha}^{-1}$ of stalk without addition of mineral N. In other words, the sludge application, based on the $\mathrm{N}$ criterion, resulted in a yield increase of $23 \%$ over the conventional treatment with mineral NPK fertilizer application, reducing the mineral phosphate fertilizer by $30 \%$ and the mineral $\mathrm{N}$ fertilizer doses recommended for sugarcane at planting by $100 \%$.

Similar results regarding the possibility of reducing $\mathrm{N}$ and $\mathrm{P}$ applications were observed by Franco et al. (2008), applying doses of 5 and $10 \mathrm{t} \mathrm{ha}^{-1}$ sludge to cane at planting. Chiba et al. (2008, 2009), applying $8.2 \mathrm{t} \mathrm{ha}^{-1}$ sludge, based on the $\mathrm{N}$ criterion, complemented fertilization with $0,45,90,135$ and $180 \mathrm{~kg} \mathrm{ha}^{-1} \mathrm{P}_{2} \mathrm{O}_{5}$ (equivalent to $0,25,50,75$, and $100 \%$ of the phosphate fertilizer recommended for cane) and found that the use of phosphate fertilizer could be cut back by $25 \%$, similar to our findings here. However, these authors did not observe higher yields when sludge was applied together with phosphate fertilizer.

The average sugar yields per hectare (tonnes of sugar per hectare-TSH) by cane-plant, as a function of the sludge rates, $\mathrm{N}$ and $\mathrm{P}$, varied from 9.3 to $17.7 \mathrm{t} \mathrm{ha}^{-1}$ (Figure 2). The sugar yield in the treatment with mineral fertilization, of $14.7 \mathrm{t} \mathrm{ha}^{-1}$, was similar to that found by Gomes (2003), who obtained a sugar yield of $15.2 \mathrm{t} \mathrm{ha}^{-1}$ for the same cultivar used in this study, when treated with conventional mineral fertilization. 
The equation for TSH of the cane-plant, by means of the response surface study, can be given as: TSH $\left(\mathrm{t} \mathrm{ha}^{-1}\right)=8.87+0.98 \mathrm{~S}+0.04 \mathrm{~N}+0.02 \mathrm{P}-0.04 \mathrm{~S}^{2}-$ $0.0002 \mathrm{~N}^{2}-0.0001 \mathrm{P}^{2}\left(\mathrm{R}^{2}=0.61 ; \mathrm{p}<0.05\right)$. The TSH values varied only in function of stalk productivity, since the total recoverable sugar content (TRS) did not differ among the treatments (Table 2). The same absence of an effect on the TRS content from the application of $\mathrm{N}$ fertilizer was also found by Korndörfer et al. (1997), who reported that the greater sugar output per area was a direct consequence of the higher stalk yield.

According to the response surface equation, the sludge application recommended by the $\mathrm{N}$ criterion $\left(10.8 \mathrm{tha}^{-1}\right)$ resulted in a sugar yield of $15.7 \mathrm{t} \mathrm{ha}^{-1}$ when complemented with $125 \mathrm{~kg} \mathrm{ha}^{-1} \mathrm{P}_{2} \mathrm{O}_{5}$ as phosphate fertilizer application, $30 \%$ less than would otherwise have been necessary. However, the maximum sugar yield of $17.4 \mathrm{t} \mathrm{ha}^{-1}$ was only obtained with addition of $57 \mathrm{~kg} \mathrm{ha}^{-1} \mathrm{~N}$ via mineral $\mathrm{N}$ fertilizer combined with sludge and phosphate fertilizer.

The technical variables of the cane, evaluated by Brix, juice Pol, cane Pol, purity, reducing sugars, total reducing sugars and TRS, were not altered by the treatments (Table 2). Similar results were reported by Marques et al. (2007). However, Bertoncini et al. (2004), applying a dose equivalent of $388 \mathrm{t} \mathrm{ha}^{-1}$ sludge to pots containing samples of Red Latosol (Oxisol), found negative effects on the cane quality, e.g., an increase in the reducing sugar content and reduction in the fiber quantity. In this case, aside from the fact that the experiment was conducted in pots and not in field and the high sludge dose (far above the permitted for agricultural use), the cane had probably not reached maturity at the time of cutting, because a late variety, $\mathrm{RB} 72-454$, was used, but harvested only 10 months after planting.

The fiber content varied according to the equation: Fiber $(\%$ cane $)=14.85-0.25 \mathrm{~S}+0.015 \mathrm{~S}^{2}\left(\mathrm{R}^{2}=0.70\right.$; $\mathrm{p}<0.05)$. In this case the maximum fiber content (14.85\%) was obtained without sludge application and the minimum $(13.90 \%)$ at a sludge dose of $10.8 \mathrm{tha}^{-1}$. Fiber levels of 10 - $11 \%$ were obtained by Tasso Júnior et al. (2007), evaluating the sludge application on cane cultivar SP 81-3250.

The assessment of the residual effect of the treatments on the first ratoon growth showed increases in TCH from 84 to $94 \mathrm{t} \mathrm{ha}^{-1}$ and in TSH
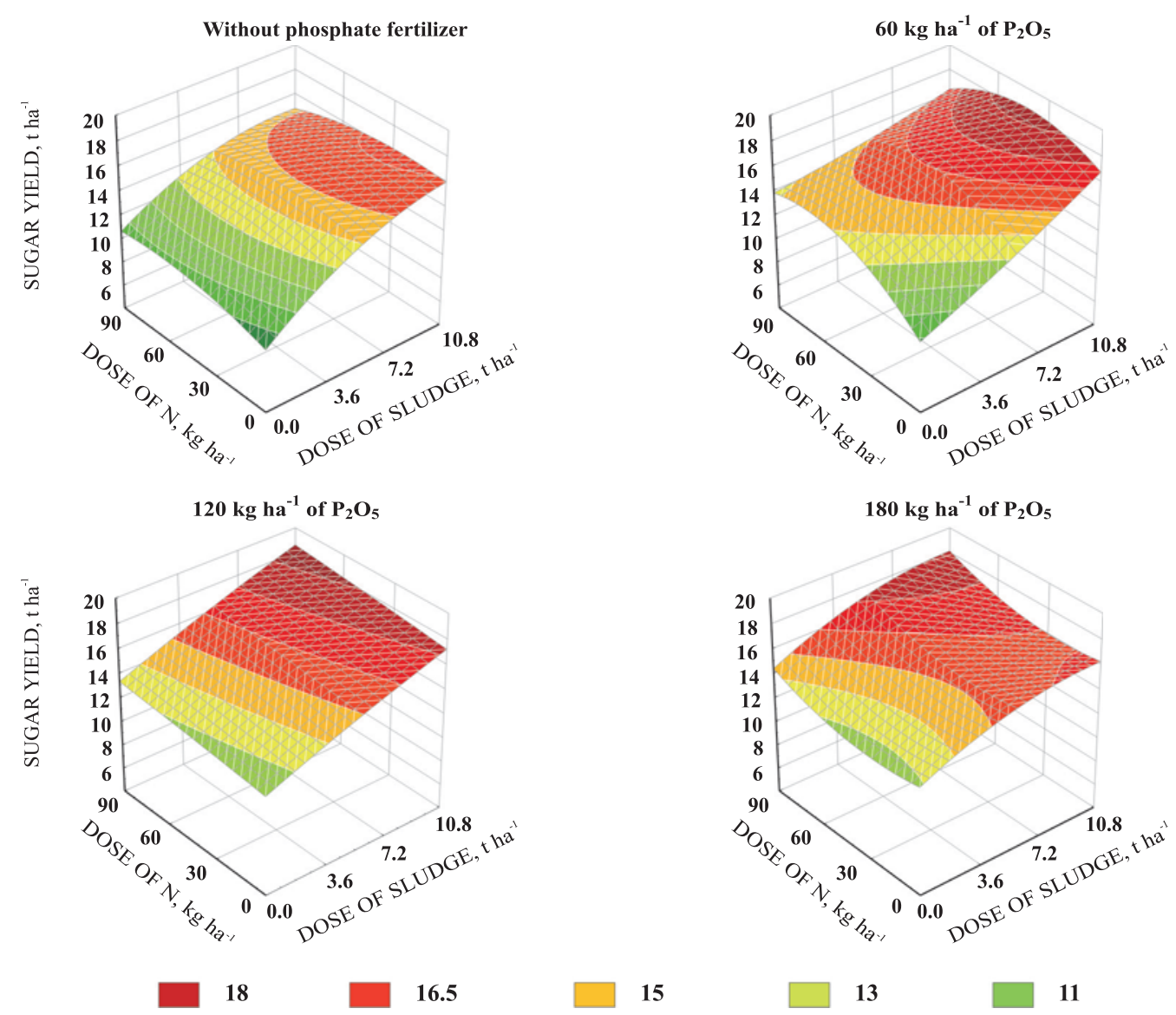

Figure 2. Average sugar yield (tonnes of sugar per hectare - TSH) of cane-plant in function of the sludge, nitrogen and phosphorous rates. 
Table 2. Technical variables of sugarcane at the time of the first harvest (cane-plant), in September/2006, and second harvest (first ratoon), in October/2007

\begin{tabular}{|c|c|c|c|c|c|c|c|}
\hline & Brix & Pol & Reducing sugars & Purity & Pol Cana & $\begin{array}{c}\text { Total } \\
\text { reducing sugars }\end{array}$ & TRS \\
\hline & \multicolumn{3}{|c|}{$\%$ in juice } & \multicolumn{3}{|c|}{$\%$ in cane (stalk) } & $\mathrm{kg} \mathrm{t}^{-1}$ \\
\hline Cane-plant & 22,67 & 20,50 & 0,44 & 90,38 & 16,71 & 18,10 & 163,25 \\
\hline $\mathrm{CV}(\%)$ & 3,45 & 4,45 & 10,70 & 1,82 & 4,27 & 4,20 & 3,99 \\
\hline Cane-ratoon & 22,66 & 20,55 & 0,54 & 90,23 & 16,87 & 18,10 & 165,02 \\
\hline CV (\%) & 8,87 & 3,59 & 5,36 & 0,94 & 3,27 & 3,10 & 3,05 \\
\hline
\end{tabular}

${ }^{(1)}$ The evaluated technical variables were the total soluble solids (Brix), juice sucrose (Pol), reducing sugars, purity, cane Pol, total reducing sugars and total recoverable sugar (TRS), according to the method described by Prado \& Pancelli (2006). CV (\%) = coefficient of variation in percentage.

from 14.2 to $15.8 \mathrm{t} \mathrm{ha}^{-1}$, respectively, in function of applying sludge at the time of planting, according to the equations TCH $\left(\mathrm{t} \mathrm{ha}^{-1}\right)=84.0+0.9 \mathrm{~S}\left(\mathrm{R}^{2}=0.55\right.$; $\mathrm{p}<0.05)$ and TSH $\left(\mathrm{t} \mathrm{ha}^{-1}\right)=14.24+0.14 \mathrm{~S}\left(\mathrm{R}^{2}=0.46\right.$; $\mathrm{p}<0.05)$. Hence, the application of $10.8 \mathrm{t} \mathrm{ha}^{-1}$ sludge at the time of planting boosted the $\mathrm{TCH}$ of the first ratoon harvest by $12 \%$ and the TSH by $11 \%$. These results were probably due to sludge mineralization, which is $10 \%$ in the second year after application, according to Cogger et al. (2004).

Similarly as for cane-plant, there was no residual effect, either beneficial or prejudicial, of the initial treatments on the technical variables of the first ratoon (Table 2). Just as for cane-plant, the higher sugar yield was a result of the greater stalk productivity. Similar results were observed by Silva et al. (2008), who observed no negative effects on the technical quality of ratoon stalks induced by applications of 5.32 and $10.65 \mathrm{t} \mathrm{ha}^{-1}$ sludge.

In view of the results obtained and the response surface model for stalk yield, a first approach of recommendation (Table 3 ) is suggested for cane growers interested in using urban waste sludge to complement conventional mineral fertilizers. The

Table 3. Suggested recommendation for nitrogen and phosphate fertilizer applications for cane planting, as related to sewage sludge rates, based on the nitrogen criterion (CONAMA, 2006)

\begin{tabular}{ccccc}
\hline $\begin{array}{c}\text { Rate of } \\
\text { sewage sludge } \\
\text { application }\end{array}$ & $\mathbf{N}$ & $\mathbf{P}_{2} \mathbf{O}_{5}$ & $\mathbf{K}_{\mathbf{2}} \mathbf{O}$ & $\begin{array}{c}\text { Estimated } \\
\text { relative } \\
\text { yield }\end{array}$ \\
\hline$\%$ & & $\mathrm{~kg} \mathrm{ha}^{-1}-$ & $\%$ \\
0 & 90 & 180 & 160 & 100 \\
33 & 80 & 154 & 160 & 109 \\
66 & 60 & 140 & 160 & 117 \\
100 & 0 & 125 & 160 & 122 \\
\hline
\end{tabular}

(1) The $100 \%$ sludge dose is equivalent to the rate of sludge application, in tha ${ }^{-1}$, as recommended by CONAMA (2006). results are valid for soils with very low $\mathrm{P}$ and potassium concentrations and for the expected yield of about $90 \mathrm{t} \mathrm{ha}^{-1}$ which corresponds to $100 \%$ of the expected relative yield, for cane-plant grown for 12 months under conventional management conditions, with liming and mineral NPK application, as recommended by Spironello et al. (1996). It can also be stated that as the sludge dose at the time of planting is increased up to the legal limit, according to the $\mathrm{N}$ criterion (CONAMA, 2006), the need for applying mineral $\mathrm{N}$ declines by up to $100 \%$ and by up to $30 \%$ for phosphate.

\section{CONCLUSIONS}

1. The application of sewage sludge at sugarcane planting, in combination with mineral NPK, boosts stalk and sugar yield and does not alter the technical variables of sugarcane in comparison with conventional applications of mineral NPK.

2. The dose recommended based on the $\mathrm{N}$ criterion enables a reduction of mineral $\mathrm{N}$ and phosphate fertilizer application and increases stalk and sugar yields.

3. There is a residual effect of the sludge applied to cane-plant on the stalk and sugar yield of the second harvest (first ratoon).

\section{ACKNOWLEDGEMENTS}

The authors thank the State of São Paulo Research Foundation (FAPESP) for financial support (grant $\mathrm{n}^{\circ}$ 2007/54720-3); the National Council for Scientific and Technological Development (CNPq) for a fellowship; $\mathrm{Mr}$. Celso Batagin for allowing the installation of this experiment in his commercial sugarcane field; and the Companhia Saneamento de Jundiaí for supplying the sewage sludge. 


\section{LITERATURE CITED}

ABREU JUNIOR, C.H.; BOARETTO, A.E.; MURAOKA, T. \& KIEHL, J.C. Uso agrícola de resíduos orgânicos: Propriedades químicas do solo e produção vegetal. TORRADO, P.V.; ALLEONI, L.R.F.; COOPER, M.; SILVA, A.P. \& CARDOSO, E.J., eds. Tópicos em ciência do solo. Viçosa, MG, Sociedade Brasileira de Ciência do Solo, 2005. v.4. p.391-479.

ABREU JUNIOR, C.H.; NOGUEIRA, T.A.R.; OLIVEIRA, F.C.; PIRES, A.M.M. \& FRANCO, A. Aproveitamento agrícola de resíduos no canavial. In: MARQUES, M.O.; MUTTON, M.A.; NOGUEIRA, T.A.R.; TASSO JÚNIOR, L.C. \& BERNARDI, J.H., eds. Tecnologias na agroindústria canavieira. Jaboticabal, FCAV, 2008. p.184-210.

BERTONCINI, E.I.; MATTIAZZO, M.E. \& ROSSETTO, R. Sugarcane yield and heavy metal availability in two biosolid-amended Oxisols. J. Plant Nutr., 27:1243-1260, 2004.

BOEIRA, R.C.; LIGO, M.A.V. \& DYNIA, J.F. Mineralização de nitrogênio em solo tropical tratado com lodo de esgoto. Pesq. Agropec. Bras., 37:1639-1647, 2002.

CAMILOTTI, F.; ANDRIOLI, I.; MARQUES, M.O.; SILVA, A.R. \& TASSO JUNIOR, L.C. Avaliação dos teores de metais pesados no solo e na planta de cana-de-açúcar sob adubação com lodo de esgoto e vinhaça. Biosci. J., 25:2331, 2009.

CAMILOTTI, F.; ANDRIOLI, I.; MARQUES, M.O.; SILVA, A.R.; TASSO JUNIOR, L.C.; NOBILE, F.O.; NOGUEIRA, G.A. \& PRATI, F. Produtividade e qualidade agroindustrial da cana-de-açúcar cultivada com lodo de esgoto, vinhaça e adubos minerais. STAB, 24:32-55, 2006.

CHIBA, M.K.; MATTIAZZO, M.E. \& OLIVEIRA, F.C. Cultivo de cana-de-açúcar em Argissolo tratado com lodo de esgoto. I - disponibilidade de nitrogênio no solo e componentes de produção. R. Bras. Ci. Solo, 32:643-652, 2008.

CHIBA, M.K.; MATTIAZZO, M.E. \& OLIVEIRA, F.C. Rendimento de cana-de-açúcar cultivada em Argissolo, utilizando lodo de esgoto como fonte de fósforo. Acta Sci. Agron., 31:495-501, 2009.

CÓ JÚNIOR, C.; MARQUES, M.O. \& TASSO JUNIOR, L.C. Efeito residual de quatro aplicações anuais de lodo de esgoto e vinhaça na qualidade tecnológica da cana-deaçúcar. Eng. Agric., 28:196-203, 2008.

COGGER, C.G.; BARY, A.I.; SULLIVAN, D.M. \& MYHRE, E.A. Biosolids processing effects on first and second year available nitrogen. Soil Sci. Soc. Am. J., 68:162-167, 2004.

COMPANHIA DE TECNOLOGIA E SANEAMENTO AMBIENTAL - CETESB. Decisão de Diretoria $n^{\circ} 195$ 2005-E. São Paulo, 2005.

CONSELHO NACIONAL DO MEIO AMBIENTE - CONAMA. Resolução n ${ }^{\circ}$ 375, de 29 de agosto de 2006. Brasília, 2006. $32 p$.
CORREAA, R.S. Efficiency of five biosolids to supply nitrogen and phosphorus to ryegrass. Pesq. Agropec. Bras., 39:1133-1139, 2004.

EMPRESA BRASILEIRA DE PESQUISA AGROPECUÁRIA EMBRAPA. Centro Nacional de Pesquisa de Solos. Sistema brasileiro de classificação de solos. Brasília, Embrapa Produção de Informação; Rio de Janeiro, Embrapa Solos, 1999. 412p.

FRANCO, A.; MARQUES, M.O. \& MELO, W.J. Sugarcane grown in an Oxisol amended with sewage and vinasse: Nitrogen contents in soil and plant. Sci. Agric., 65:408414, 2008 .

GOMES, J.F.F. Produção de colmos e exportação de macronutrientes primários por cultivares de cana-deaçúcar (Saccharum spp.). Piracicaba, Universidade de São Paulo, 2003. 65p. (Tese de Mestrado)

KORNDÖRFER, G.H.; VALLE, M.R.; MARTINS, M. \& TRIVELIN, P.C.O. Aproveitamento do nitrogênio da uréia pela cana-planta. R. Bras. Ci. Solo, 21:23-26, 1997.

MARQUES, M.O.; BELLINGIERRI, P.A.; MARQUES, T.A. \& NOGUEIRA, T.A.R. Qualidade e produtividade de canade-açúcar cultivada em solo com doses crescentes de lodo de esgoto. Biosci. J., 23:111-122, 2007.

MAULE, R.F.; MAZZA, J.A. \& MARTHA JUNIOR, G.B. Produtividade agrícola de cultivares de cana-de-açúcar em diferentes solos e épocas de colheita. Sci. Agric., 58:295301, 2001.

NASCIMENTO, C.W.A.; BARROS, D.A.S.; MELO, E.E.C. \& OLIVEIRA, A.B. Alterações químicas em solos e crescimento de milho e feijoeiro após aplicação de lodo de esgoto. R. Bras. Ci. Solo, 28:385-392, 2004.

OLIVEIRA, F.C. Disposição de lodo de esgoto e composto de lixo urbano num Latossolo Vermelho-Amarelo cultivado com cana-de-açúcar. Piracicaba, Universidade de São Paulo, 2000. 247p. (Tese de Doutorado)

ORLANDO FILHO, J.; RODELLA, A.A.; BELTRAME, J.A. \& LAVORENTI, N.A. Doses, fontes e formas de aplicação de nitrogênio em cana-de-açúcar. STAB, 17:39-41, 1999.

PRADO R.M. \& PANCELLI, M.A. Nutrição nitrogenada em soqueiras e a qualidade tecnológica da cana-de-açúcar. STAB, 25:60-63, 2006.

RAIJ, B.van; ANDRADE, J.C.; CANTARELLA, H. \& QUAGGIO, J.A. Análise química para avaliação da fertilidade de solos tropicais. Campinas, Instituto Agronômico de Campinas, 2001. 285p.

SILVA, F.C.; BOARETTO, A.E.; BERTON, R.S.; ZOTELLI, H.B.; PEXE, C.A. \& BERNARDES, E.M. Efeito de lodo de esgoto na fertilidade de um Argissolo VermelhoAmarelo cultivado com cana-de-açúcar. Pesq. Agropec. Bras., 36:831-840, 2001. 
SILVA, M.A.; JERONIMO, E.M. \& LÚCIO, A.D. Perfilhamento e produtividade de cana-de-açúcar com diferentes alturas de corte e épocas de colheita. Pesq. Agropec. Bras., 43:979986, 2008

SPIRONELLO, A.; RAIJ, B.van; PENATTI, C.P.; CANTARELLA, H.; MORELLI, J.L.; ORLANDO FILHO, J.; LANDELL, M.G.A. \& ROSSETTO, R. Cana-de-açúcar. In: RAIJ, B.van; CANTARELLA, H.; QUAGGIO, J.A. \& FURLANI, A.M.C., eds. Recomendações de adubação e calagem para o Estado de São Paulo. Campinas, Fundação IAC, 1996. p.237-239. (Boletim, 100)
TASSO JÚNIOR, L.C.; MARQUES, M.O.; FRANCO, A.; NOGUEIRA, G.A.; NOBILE, F.O.; CAMILOTTI, F. \& DA SILVA, A.R. Produtividade e qualidade de cana-de-açúcar cultivada em solo tratado com lodo de esgoto, vinhaça e adubos minerais. Eng. Agric., 27:276-283, 2007.

USEPA. SW-846 Manual. Washington, 2006. Disponível em $<$ http://www.epa.gov/epaoswer/hazwaste/test/ sw846.htm>. Acesso em 08 de maio de 2006.

UNITED STATES. Department of Agriculture. Soil taxonomy: A basic system of soil classification for making and interpreting soil surveys. Washington, USDA, 1999. 869p. (Handbook, 436) 